\title{
AKRUAL
}

Jurnal Akuntansi

http://fe.unesa.ac.id/ojs/index.php/akrl

\section{TOTAL BENCHMARKING SEBAGAI ALAT MENILAI KEWAJARAN LAPORAN KEUANGAN DAN PEMENUHAN KEWAJIBAN PERPAJAKAN}

\author{
Bayu Sarjono \\ STIE Perbanas Surabaya \\ email: bayu@perbanas.ac.id \\ Artikel diterima: 14 Mei 2014 \\ Terakhir direvisi: 27 Juli 2014
}

\begin{abstract}
The objective of this research is to provide empirical evidence on the utilization of total benchmarking ratio as a mean to assess the fairness of financial statement and the fulfilment of tax obligation in financial intermediaries sector. Variables to be tested in this research are 14 ratio of benchmarking total consist of: Gross Profit Margin (GPM), Operating Profit Margin (OPM), Pretax Profit Margin (PPM), Corporate Tax to Turn Over Ratio (CTTOR), Net Profit Margin (NPM), Dividend Payout Ratio (DPR), Value-added Tax Ratio (pn), Salary/Sales Ration (g), Interest/Sales Ratio (b), Rent/Sales Ratio (s), Depreciation/Sales Ratio (py), Outside-business Revenue/Sales Ratio (pl), Outside-business Cost/ Sales (bl), Other-input/Sales Ratio ( $x$ ). This research incorporates financial intermediaries sector because it has contributed to the 5 largest tax revenue in last 5 years. The research method used is descriptive qualitative method by calculating ratios then compare them to the benchmark set by the Directorate General of Taxes. The sample of this research is Business Field Classification (Klasifikasi Lapangan Usaha) in the financial intermediary sector: foreign exchange banks, insurance and consumer financing companies. The type of data used is secondary data, that is audited financial statements gathered form ICMD. The research results show that the largest ratio difference for foreign exchange banks and insurance companies is at interest expense; however, the largest ratio difference for consumer financing is at outside-business Costs.
\end{abstract}

Keywords: Total Benchmarking, Tax Payer Compliance, Tax Obligation, Business Field Classification.

\section{PENDAHULUAN}

Pajak merupakan sumber utama pendanaan suatu Negara, baik dengan tujuan pembangunan, pertahanan maupun pelaksanaan administrasi pemerintahan.Faktor dominan dari pajak tersebut, menyebabkan banyak kepentingan ada di dalamnya.Mulai dari kepentingan orang pribadi, pengusaha, badan usaha hingga kepentingan politik. Banyaknya kepentingan yang mendominasi perpajakan, menyebabkan timbulnya perilaku yang menyimpang 
berupa kepatuhan yang semu atas pemenuhan kewajiban perpajakan yang dilakukan oleh Wajib Pajak.

Dalam rangka meningkatkan pembinaan dan pengawasan terhadap Wajib Pajak oleh Kantor Pelayanan Pajak, Kantor Pusat Direktorat Jenderal Pajak telah menyusun rasio total benchmarking. Rasio total benchmarking tersebut dapat digunakan sebagai alat bantu untuk menilai kewajaran kinerja keuangan dan pemenuhan kewajiban perpajakan oleh Wajib Pajak. Rasio Total Benchmarking memiliki karakteristik sebagai berikut :Rasio Total Benchmarking disusun berdasarkan kelompok usaha, Benchmarking dilakukan atas rasio-rasio yang berkaitan dengan tingkat laba dan input-input perusahaan, Ada keterkaitan antar rasio benchmark, Fokus pada penilaian kewajaran kinerja keuangan dan pemenuhan kewajiban perpajakan. Total benchmarking hanya merupakan suatu alat bantu (supporting tools) yang dapat digunakan oleh aparat pajak dalam membina wajib pajak dan menilai kepatuhan Perpajakannya.

Benchmarking merupakan suatu proses yang telah secara umum diterapkan dalam dunia usaha. Benchmarking dalam dunia bisnis merupakan suatu proses sistematik dalam membandingkan produk, jasa atau praktik suatu organisasi terhadap kompetitor atau pemimpin industri untuk menentukan apa yang harus dilakukan dalam mencapai tingkat kinerja yang tinggi. Dalam melakukan benchmarking, suatu organisasi membandingkan nilai-nilai tertentu (dari dalam organisasi) dengan suatu titik referensi atau standar keunggulan yang sebanding2. Dengan melakukan pembandingan tersebut, perusahaan dapat melakukan evaluasi dan kemudian menentukan langkah yang sistematik dan terarah untuk mencapai tujuan yang diharapkan.Model ini diadopsi pula oleh Direktorat Jenderal Pajak dalam rangka melaksanakan fungsinya memberikan bimbingan dan pengawasan terhadap wajib pajak. Dengan berasumsi bahwa wajib pajak dengan karakteristik yang sama akan cenderung memiliki perilaku bisnis yang sama, kondisi keuangan dan perpajakan masing-masing wajib pajak dapat dibandingkan dengan suatu benchmark yang mewakili karakteristik wajib pajak yang bersangkutan. Dengan melakukan pembandingan tersebut, diharapkan Direktorat Jenderal Pajak dapat secara sistematis mendeteksi wajib pajak dengan risiko ketidakpatuhan yang tinggi, untuk kemudian dapat dilakukan tindak lanjut yang sesuai.

Penelitian ini dilakukan untuk menguji kembali apakah rasio total benchmarking yang dikeluarkan oleh Direktorat Jendral Pajak telah menggambarkan keadaan riil dari Wajib Pajak Indonesia. Penggunaan Sektor Perantara Keuangan dikarenakan sektor ini menjadi penyumbang penerimaan pajak terbesar ketiga setelah sektor industri pengolahan dan sektor perdagangan besar dan eceran.

Berdasarkan latar belakang yang disampaikan, maka permasalahan dalam penelitian ini dirumuskan sebagai berikut: Apakah kinerja keuangan Perusahan di Sektor Perantara Keuangan sudah memenuhi rasio total benchmarking dalam menilai kewajaran laporan keuangan dan pemenuhan kewajiban perpajakan?

Penelitian ini mempunyai tujuan untuk menjawab masalah penelitian yaitu untuk mengetahui kewajaran kinerja keuangan dan pemenuhan kewajiban perpajakan pada Perusahaan Sektor Perantara Keuangan berdasarkan rasio total benchmarking. 


\section{KAJIAN PUSTAKA}

\section{Penelitian Terdahulu}

Berikut ini dijelaskan beberapa penelitian empiris yang membahas tentang tasio total benchmarking antara lain :

a. Nyoman Darmayasa dan Nyoman Sentosa Hardika. (2011) yang meneliti Perencanaan Pajak dari Aspek Rasio Total Benchmarking, Kebijakan Akuntansi, dan Administrasi Sebagai Strategi Penghematan Pajak.Perencanaan pajak merupakan tahap pertama dalam penghematan pajak. Strategi penghematanpajak disusun pada saat perencanaan. Oleh karena itu. Penelitiandan pengumpulan ketentuan peraturan perpajakan dilakukan pada tahap ini dengan maksud dapat diseleksi jenis tindakan penghematan pajak yang akandilakukan. Pada uinunmya penekanan perencanaan pajak (tax planning) adalah untuk meminimumkan kewajiban pajak. Perencanaan pajak merupakan upaya legal yang bisa dilakukan wajib pajak. Tindakan tersebut legal karena penghematan pajak hanya dilakukan dengan memanfaatkan halhal yang tidak diatur (loopholes). Rasio total benchmarking merupakan salah satu aspek yang harus diperhatikan dalam penyusunan perencanaan pajak. Rasio total benchmarking sudah ditetapkan sampai pada tahap V dengan total 105 Klasifikasi Lapangan Usaha (KLU). Dalam penyusunan perencanaan pajak, Wajib Pajak harus memperhatikan rasio-rasio yang sesuai dengan KLU perusahaannya.sehingga bisa terhindar adanya himbauan dari KPP dan tahapan konseling.

b. Damayanti, Theresia Woro dan Sukmono A, Eko (2011). Yang meneliti tentang Ratio Total Benchmarking Sesuaikah Dengan Kondisi Wajib Pajak? (Studi Pada Empat Perusahaah Rokok Yang Terdaftar Di BEI). Bahwa terdapat perbedaan antara rasio benchmarking pada perusahaan rokok yang terdaftar di BEI dibandingkan dengan acuan rasio benchmarking yang dikeluarkan oleh Dirjen Pajak. Terdapat perbedaan pada setiap rasio,yaitu perbedaan terbesar terdapat pada rasio pembayaran deviden (DPR), yaitu rata-rata sebesar 31.50\% jauh dibawah benchmark. Sedangkan perbedaan terkecil terdapat pada rasio Sewa(s) yaitu rata-rata sebesar $0.13 \%$ dibawah benchmark, yang dapat diartikan bahwa setiap perusahaan memiliki karakter dan kondisi keuangan yang berbeda-beda

\section{Konsep Benchmarking}

Sistem pengukuran kinerja merupakan kunci untuk memandu dan menguji hasil dari proses perbaikan, tetapi tidak mengindikasikan bagaimana suatu proses harus di perbaiki. Salah satu pendekatan yang dapat membantu melengkapi hal tersebut adalah benchmarking.Dattakumar (2003) menyimpulkan bahwa pendekatan benchmarking dapat digunakan untuk perbaikan terus menerus. Hasil review Grunberg (2003) terhadap metoda-metoda yang digunakan untuk perbaikan kinerja aktivitas operasional pada perusahaan manufaktur menunjukkan bahwa pendekatan benchmarking juga memungkinkan untuk digunakan. Gleich et al. (2008) menyebutkan bahwa benchmarking dapat digunakan untuk meningkatkan kinerja pada berbagai area.

Berbagai definisi benchmarking antara lain 1) merupakan suatu proses untuk mengukur kinerja terhadap perusahaan yang terbaik dalam kelasnya, 
kemudian menggunakan analisis untuk memenuhi dan melebihi perusahaan tersebut (Pryor dan Katz 1993 dalam Yasin 2002), 2) pencarian praktek terbaik yang mengarah kepada kinerja yang sangat baik apabila praktek-praktek tersebut diterapkan (Partovi 1994), 3) proses identifikasi dan pembelajaran dari praktek terbaik dimanapun di dunia (Allan 1997 dalam Elmuti dan Yunus 1997), dan 4) perbandingan sistematis terhadap proses dan kinerja untuk menciptakan standar baru dan atau meningkatkan proses (Steven et al.2003).

\section{Total Benchmarking}

Benchmarking yang dilakukan oleh Direktorat Jenderal Pajak disusun dalam suatu konsep yang disebut Total Benchmarking. Total Benchmarking didefinisikan sebagai proses membandingkan rasio-rasio yang terkait dengan tingkat laba perusahaan dan berbagai input dalam kegiatan usaha dengan rasiorasio yang sama yang dianggap standar untuk kelompok usaha tertentu, serta melihat hubungan keterkaitan antar rasio untuk menilai kewajaran kinerja keuangan dan pemenuhan kewajiban perpajakan Wajib Pajak. Dengan demikian total benchmarking memiliki karakteristik:

a. Benchmark disusun berdasarkan kelompok usaha.

b. Benchmarking dilakukan atas rasio-rasio berkaitan dengan tingkat laba dan input-input perusahaan.

c. Hubungan keterkaitan antar rasio-rasio diperhatikan.

d. Fokus pada penilaian kewajaran kinerja keuangan dan pemenuhan kewajiban perpajakan.

Rasio merupakan alat yang penting dalam melakukan analisa laporan keuangan.Rasio (\%) digunakan untuk mengkonversi angka-angka dalam laporan keuangan ke dalam bentuk yang lebih layak untuk diperbandingkan dengan data tahun-tahun lainnya untuk satu wajib pajak (vertikal) ataupun dibandingkan antar wajib pajak dalam bidang industri tertentu (horizontal). Rasio bisa lebih menggambarkan posisi satu wajib pajak dibandingkan dengan wajib pajak lainnya dalam satu industri yang sama dibandingkan dengan angka-angka rupiah laporan keuangan. Secara umum, analisa rasio akan berguna untuk:

a. memahami kinerja satu industri;

b. membandingkan kinerja perusahaan (wajib pajak) dengan benchmark-nya;

c. melakukan komparasi dengan tahun-tahun lainya;

d. membantu dalam menentukan tingkat risiko ketidakpatuhan di wajib pajak.

Benchmarking seringkali menjadi pintu masuk oleh Account Representativedalam menilai tingkat kewajaran pembayaran pajak oleh Wajib Pajak dan sebagai bentuk pembinaan dan pengawasan terhadap Wajib Pajak oleh Kantor Pelayanan Pajak.

\section{Tujuan dan Manfaat Total Benchmarking}

Tujuan Total Benchmarking antara lain:

a. Menjadi pedoman dan sebagai pembanding dengan kondisi SPT Tahunan yang dilaporkan Wajib Pajak;

b. Membantu pengawasan kepatuhan Wajib Pajak, terutama menyangkut kepatuhan materialnya. 
Manfaat Total Benchmarking adalah :

a) Supporting tools bagi program intensifikasi penggalian potensi pajak;

b) Alat bantu dalam penghitungan tax gap.

\section{Proses dan metode penetapan benchmark}

Total benchmarking merupakan salah satu dari langkah strategis yang berkaitan dengan upaya penggalian potensi penerimaan pajak untuk mengamankan penerimaan pajak tahun 2009 dan tahun tahun selanjutnya. Program ini merupakan bagian dari program penggalian potensi pajak melalui program mapping, profilling, benchmarking, pertukaran data dan perekaman. Penetapan rasio-rasio benchmark secara teknis dilakukan sebagai berikut:

1. Nilai rasio-rasio benchmark ditetapkan untuk masing-masing kelompok usaha berdasarkan 5 (lima) digit kode Klasifikasi Lapangan Usaha (KLU) Wajib Pajak. Klasifikasi Lapangan Usaha dimaksud adalah KLU sesuai Keputusan Direktur Jenderal Pajak nomor KEP-34/PJ/2003 tanggal 14 Februari 2003.

2. Penetapan rasio-rasio benchmark untuk keseluruhan kelompok usaha dilakukan secara bertahap oleh Kantor Pusat Direktorat Jenderal Pajak.

3. Penetapan rasio benchmark menggunakan data perpajakan tahun 2005 sd. 2007.

4. Sumber data yang digunakan dalam tahap awal pembentukan benchmark adalah data internal dalam sistem informasi perpajakan DJP, yang terdiri dari :

a. Elemen-elemen Surat Pemberitahuan (SPT) Tahunan PPh Badan;

b. Elemen-elemen Surat Pemberitahuan Masa PPN;

c. Elemen-elemen transkrip Laporan Keuangan.

\section{Rasio-rasio Benchmark}

Rasio-rasio yang digunakan dalam total benchmarking meliputi 14 rasio yang terdiri dari rasio-rasio yang mengukur kinerja operasional, rasio input, rasio PPN dan rasio aktivitas luar usaha. Pemilihan 14 rasio tersebut didasarkan pada pertimbangan bahwa rasio yang digunakan sedapat mungkin mampu memberikan gambaran secara menyeluruh atas kegiatan operasional perusahaan dalam suatu periode dan berkaitan dengan semua jenis pajak yang menjadi kewajiban wajib pajak. Rasio-rasio tersebut meliputi:

1. Gross Profit Margin (GPM)

2. Operating Profit Margin (OPM)

3. Pretax Profit Margin (PPM)

4. Corporate Tax to Turn Over Ratio (CTTOR)

5. Net Profit Margin (NPM)

6. Dividend Payout Ratio (DPR)

7. Rasio PPN (pn)

8. Rasio Gaji/Penjualan (g)

9. Rasio Bunga/Penjualan (b)

10. Rasio Sewa/Penjualan (s)

11. Rasio Penyusutan/Penjualan (py)

12. Rasio Penghasilan Luar Usaha/Penjualan (pl)

13. Rasio Biaya Luar Usaha/Penjualan (bl)

14. Rasio Input Lainnya/Penjualan (x) 
Dengan mengukur rasio GPM, OPM, PPM, CTTOR, NPM, pl, dan bl didapatkan gambaran yang utuh mengenai kegiatan/operasi perusahaan dalam suatu tahun pajak sebagaimana tercermin dalam Penghitungan Laba Rugi (income statement) perusahaan. Pengukuran secara utuh tersebut diperlukan agar aparat pajak dapat melakukan diagnosa secara tepat dalam menentukan elemen apa dari penghitungan laba rugi perusahaan tersebut yang mengindikasikan ketidakwajaran. Pada prinsipnya, rasio-rasio tersebut merupakan rasio yang dihasilkan dari analisis vertikal suatu Penghitungan Laba Rugi Perusahaan

\section{METODE PENELITIAN \\ Rancangan Penelitian}

Jenis penelitian yang digunakan adalah kualitatif deskriptif, yang bertujuan untuk menggambarkan dan mengungkapkan suatu masalah, keadaan, peristiwa sebagaimana adanya atau mengungkap fakta secara lebih mendalam mengenai Total Benchmarking dalam menilai kewajaran laporan keuangan dan pemenuhan kewajiban perpajakan. Menurut Sukardi (2009:14) penelitian deskriptif adalah penelitian yang berusaha menggambarkan kegiatan penelitian. Penelitian deskriptif ini juga disebut penelitian pra eksperimen karena dalam penelitian ini dilakukan eksplorasi, menggambarkan, dengan tujuan untuk dapat menerangkan dan memprediksi terhadap suatu gejala yang berlaku atas dasar data yang diperoleh di lapangan. Sedangkan penelitian kuantitatif adalah penelitian ilmiah yang sistematis terhadap bagian-bagian dan fenomena serta hubungan-hubungannya. Dalam penelitian ini, menggunakan sumber data sekunder.

\section{Populasi dan Sampel Penelitian}

Populasi dalam penelitian ini adalah Wajib Pajak yang termasuk dalam Klasifikasi Lapangan Usaha Perantara Keuangan. Sampel dalam penelitian ini adalah Perusahaan-perusahaan yang termasuk dalam sektor perantara keuangan yaitu perbankan (bank devisa), asuransi (non jiwa), dan financial institution (pembiayaan konsumen) yang terdaftar di Bursa Efek Indonesia dalam kurun waktu 2005-2007.

\section{Jenis dan Sumber Data}

Jenis data yang digunakan dalam penelitian ini adalah data kuantitatif, yaitu data laporan keuangan perusahaan sektor perantara keuangan periode 20052007 dan datatotal benchmarking perpajakan tahun 2005-2007.

Sumber data dalam penelitian ini adalah data sekunder yaitu data-data yang diperoleh dari sumber data tidak langsung oleh peneliti.Data dalam penelitian ini diperoleh dari ICMD.

\section{Teknik Analisis Data}

Analisis data adalah sebuah proses yang dilakukan melalui pencatatan, penyusunan, pengolahan dan penafsiran, serta menghubungkan makna data yang ada dalam kaitannya dengan masalah penelitian. Dalam penelitian ini, data dianalisis dengan cara :

1. Melakukan perhitungan rasio yang meliputi 14 rasio total benchmarking: 
a. Gross Profit Margin (GPM), yaitu rasio antara laba kotor terhadap penjualan;

b. Operating Profit Margin (OPM), yaitu rasio antara laba bersih dari operasi terhadap penjualan;

c. Pretax Profit Margin (PPM), yaitu rasio antara laba bersih sebelum dikenakan pajak penghasilan terhadap penjualan;

d. Corporate Tax to Turn Over Ratio (CTTOR), yaitu rasio antara pajak penghasilan terutang terhadap penjualan;

e. Net Profit Margin (NPM), yaitu rasio antara laba bersih setelah pajak penghasilan terhadap penjualan;

f. Dividend Payout Ratio (DPR), yaitu rasio antara jumlah dividen tunai yang dibayarkan terhadap laba bersih setelah pajak;

g. Rasio PPN Masukan, yaitu rasio antara jumlah PPN Masukan yang dikreditkan dalam satu tahun pajak terhadap Penjualan, tidak termasuk pajak masukan yang dikreditkan dari transaksi antar cabang;

h. Rasio biaya gaji terhadap penjualan;

i. Rasio biaya bunga terhadap penjualan;

j. Rasio biaya sewa terhadap penjualan;

k. Rasio biaya penyusutan terhadap penjualan;

1. Rasio "input antara" lainnya terhadap penjualan;

m. Rasio penghasilan luar usaha terhadap penjualan; dan

n. Rasio biaya luar usaha terhadap penjualan

2. Membandingkan masing-masing rasio yang ada dengan rasio benchmark.

3. Menganalisis rasio-rasio apa saja yang di bawah dan di atas benchmark

\section{HASIL DAN PEMBAHASAN}

\section{Pengujian Kepatuhan Wajib Pajak}

Penggunaan rasio-rasio benchmark untuk melakukan pengujian kepatuhan terhadap Wajib Pajak. Aspek yang dapat diuji menggunakan benchmark meliputi:

a. Biaya Usaha

b. Koreksi Fiskal

c. Penghasilan dan Biaya Luar Usaha

d. Objek Pemotongan dan Pemungutan PPh

e. Kewajaran Pajak Masukan

Dari kelima aspek di atas, untuk poin e kewajaran pajak masukan tidak dapat dilakukan pengujian karena sektor perantara keuangan ini merupakan sektor yang dikecualikan dari pengenaan PPN yang diatur dalam Undang-Undang PPN. 


\section{Pengujian Benchmark Bank Devisa}

Tabel 1.Rasio Benchmark Bank Devisa 2005

\begin{tabular}{llccc}
\hline \multicolumn{1}{c}{ Rasio Benchmarking } & \multicolumn{3}{c}{$\mathbf{2 0 0 5}$} \\
\hline & Biaya Usaha & WP & BENCH & SELISIH \\
1 & HPP & 41,82 & 33,07 & 8,75 \\
2 & Biaya Usaha Lain & 44,98 & 34,52 & 10,46 \\
3 & Total Biaya Usaha & 86,8 & 67,59 & 19,21 \\
& Koreksi Fiskal & WP & BENCH & SELISIH \\
1 & CTTOR / PPM & 0,35 & 0,31 & 0,04 \\
& Penghasilan \& Biaya diluar usaha & WP & BENCH & SELISIH \\
1 & pl & 3,47 & 1,19 & 2,28 \\
2 & bl & 1,33 & 0,14 & 1,19 \\
& Netto (pl-bl) & 2,14 & 1,05 & 1,09 \\
& Pemotongan dan Pemungutan PPh & WP & BENCH & SELISIH \\
1 & Gaji & 15,4 & 18,69 & $-3,29$ \\
2 & Sewa & 2,37 & 1,89 & 0,48 \\
3 & Bunga & 55,03 & 18,38 & 36,65 \\
4 & Input lain & 18,37 & 12,37 & 6,00 \\
\hline
\end{tabular}

Tabel 2. Rasio Benchmark Bank Devisa 2006

\begin{tabular}{llccc}
\hline No & \multicolumn{1}{c}{ Rasio Benchmarking } & $\mathbf{2 0 0 6}$ \\
\hline & Biaya Usaha & WP & BENCH & SELISIH \\
1 & HPP & 54,25 & 35,87 & 18,38 \\
2 & Biaya Usaha Lain & 32,97 & 35,52 & $-2,55$ \\
3 & Total Biaya Usaha & 87,22 & 71,39 & 15,83 \\
& Koreksi Fiskal & WP & BENCH & SELISIH \\
1 & CTTOR / PPM & 0,31 & 0,31 & 0 \\
& Penghasilan \& Biaya diluar usaha & WP & BENCH & SELISIH \\
1 & pl & 1,19 & 0,5 & 0,69 \\
2 & bl & 1,28 & 0,15 & 1,13 \\
& Netto (pl-bl) & $-0,09$ & 0,35 & $-0,44$ \\
& Pemotongan \& Pemungutan PPh & WP & BENCH & SELISIH \\
1 & Gaji & 12,83 & 17,17 & $-4,34$ \\
2 & Sewa & 1,8 & 1,82 & $-0,02$ \\
3 & Bunga & 60,46 & 19,21 & 41,25 \\
4 & Input lain & 15 & 13,75 & 1,25 \\
\hline
\end{tabular}

Tabel 3. Rasio Benchmark Bank Devisa 2007

\begin{tabular}{llccc}
\hline No. & \multicolumn{1}{c}{ Rasio Benchmarking } & $\mathbf{2 0 0 7}$ \\
\hline & Biaya Usaha & WP & BENCH & SELISIH \\
1 & HPP & 42,36 & 36,13 & 6,23 \\
2 & Biaya Usaha Lain & 38,4 & 34,85 & 3,55 \\
3 & Total Biaya Usaha & 80,76 & 70,98 & 9,78 \\
& Koreksi Fiskal & WP & BENCH & SELISIH \\
1 & CTTOR / PPM & 0,33 & 0,38 & $-0,05$ \\
& Penghasilan \& Biaya diluar usaha & WP & BENCH & SELISIH \\
\hline
\end{tabular}




\begin{tabular}{clccc}
\hline No. & \multicolumn{1}{c}{ Rasio Benchmarking } & $\mathbf{2 0 0 7}$ & \\
\hline 1 & pl & 1,18 & 0,69 & 0,49 \\
2 & bl & 1,51 & 0,23 & 1,28 \\
& Netto (pl-bl) & $-0,33$ & 0,46 & $-0,79$ \\
& Pemotongan dan Pemungutan PPh & WP & BENCH & SELISIH \\
1 & Gaji & 14,97 & 16,67 & $-1,7$ \\
2 & Sewa & 1,85 & 1,82 & 0,03 \\
3 & Bunga & 53,01 & 11,91 & 41,1 \\
4 & Input lain & 16,66 & 29,76 & $-13,1$ \\
\hline
\end{tabular}

Berdasarkan perbandingan yang dilakukan, diketahui bahwa kinerja operasional perusahaan di atas benchmark. Jika dianalisis lebih lanjut, dapat di jelaskan sebagai berikut:

\section{Aspek Biaya Usaha}

a. Berdasarkan pembandingan diatas diketahui bahwa kinerja operasional perusahaan di atas benchmark.

b. Tingginya beban usaha tersebut karena HPP dan Biaya Usaha lain yang berada diatas benchmark. Hal ini disebabkan dari Rasio bunga terhadap penjualan menunjukkan selisih yang cukup tinggi di atas benchmark. Untuk dapat melakukan analisis secara tepat terhadap hasil pembandingan tersebut, diperlukan pemahaman menyeluruh mengenai kondisi industri pada umumnya.

c. Dari selisih-selisih tersebut terlihat bahwa selisih Biaya bunga terhadap benchmark memiliki tingkat risiko ketidakwajaran yang paling tinggi. Untuk itu, penelitian perlu difokuskan pada akun-akun yang berkaitan dengan biaya bunga.

\section{Koreksi Fiskal}

a. CTTOR/PPM Wajib Pajak diatas benchmark, yang berarti koreksi fiskal yang dilakukan wajib pajak masih dibawah benchmark perusahaan sejenis.

b. Makin besar CTTOR menunjukkan makin besar proporsi hasil penjualan perusahaan yang digunakan untuk membayar Pajak Penghasilan.

\section{Penghasilan dan Biaya Luar Usaha}

a. Hasil pembandingan menunjukkan bahwa Penghasilan Luar Usaha Netto Wajib Pajak berada diatas benchmark, dengan nilai pl dan bl keduanya diatas benchmark.

b. Tingginya $\mathrm{pl}$ bisa terjadi karena adanya penghasilan luar usaha yang bersifat insidentil yang diterima oleh Wajib Pajak pada tahun yang bersangkutan, atau penghasilan lain yang diterima secara rutin oleh Wajib Pajak diluar dari usaha pokok Wajib Pajak yang tidak secara umum juga diterima oleh perusahaan lain dalam usaha sejenis.

c. Karena rasio Penghasilan Luar Usaha diatas secara netto berada diatas benchmark, pendalaman lebih lanjut mengenai penghasilan luar usaha ini tidak perlu menjadi prioritas.

\section{Objek Pemotongan dan Pemungutan PPh}

a. Hasil analisis menunjukkan bahwa Rasio Gaji/Penjualan berada dibawah benchmark, perlu diteliti lebih dalam apakah masih terdapat potensi Pemotongan dan Pemungutan PPh Pasal 21 yang masih dapat digali dengan 
memperhatikan alasan-alasan yang mungkin mengenai rendahnya rasio tersebut.

b. Rasio Bunga/Penjualan terlihat berada di atas benchmark, menunjukkan tingginya potensi PPh Pemotongan dan Pemungutan yang masih dapat digali.

\section{Pengujian Benchmark Asuransi}

Tabel 4. Rasio Benchmark Asuransi 2005

\begin{tabular}{llccc}
\hline No & \multicolumn{2}{c}{ Rasio Benchmarking } & \multicolumn{3}{c}{$\mathbf{2 0 0 5}$} \\
\hline & Biaya Usaha & WP & BENCH & SELISIH \\
1 & HPP & 62,8 & 54,43 & 8,37 \\
2 & Biaya Usaha Lain & 28,08 & 28,61 & 0,53 \\
3 & Jumlah Biaya Usaha & 90,88 & 83,04 & 7,84 \\
& Koreksi Fiskal & WP & BENCH & SELISIH \\
1 & CTTOR / PPM & 0,11 & 0,3 & $-0,19$ \\
& Penghasilan \& Biaya diluar usaha & WP & BENCH & SELISIH \\
1 & Pl & 1,92 & 8,67 & $-6,75$ \\
2 & Bl & 0,16 & 0,06 & 0,16 \\
& Netto (pl-bl) & 1,8 & 8,61 & $-6,91$ \\
& Pemotongan dan Pemungutan PPh & WP & BENCH & SELISIH \\
1 & Gaji & 15,12 & 14,69 & 0,43 \\
2 & Sewa & 0,61 & 2,94 & $-2,33$ \\
3 & Bunga & 62,8 & 0 & 62,8 \\
4 & Input lain & 9,38 & 22,53 & $-13,15$ \\
\hline
\end{tabular}

Tabel 5. Rasio Benchmark Asuransi 2006

\begin{tabular}{llccc}
\hline No & \multicolumn{1}{c}{ Rasio Benchmarking } & \multicolumn{3}{c}{$\mathbf{2 0 0 6}$} \\
\hline & Biaya Usaha & WP & BENCH & SELISIH \\
1 & HPP & 64,2 & 54,43 & 9,77 \\
2 & Biaya Usaha Lain & 29,71 & 28,61 & 1,1 \\
3 & Jumlah Biaya Usaha & 93,91 & 83,04 & 10,87 \\
& Koreksi Fiskal & WP & BENCH & SELISIH \\
1 & CTTOR / PPM & 0,09 & 0,3 & $-0,22$ \\
& Penghasilan \& Biaya diluar usaha & WP & BENCH & SELISIH \\
1 & Pl & 0,76 & 8,67 & $-7,91$ \\
2 & Bl & 0,5 & 0,06 & 0,44 \\
& Netto (pl-bl) & 0,26 & 8,61 & $-8,35$ \\
& Pemotongan dan Pemungutan PPh & WP & BENCH & SELISIH \\
1 & Gaji & 13,7 & 14,69 & $-0,99$ \\
2 & Sewa & 0,53 & 2,94 & $-2,41$ \\
3 & Bunga & 64,2 & 0 & 64,2 \\
4 & Input lain & 9,53 & 22,53 & -13 \\
\hline
\end{tabular}


Tabel 6. Rasio Benchmark Asuransi 2007

\begin{tabular}{llccc}
\hline No & \multicolumn{1}{c}{ Rasio Benchmarking } & \multicolumn{3}{c}{$\mathbf{2 0 0 7}$} \\
\hline & Biaya Usaha & WP & BENCH & SELISIH \\
1 & HPP (100\% - GPM) & 69,68 & 54,43 & 15,25 \\
2 & Biaya Usaha Lain (GPM-OPM) & 27,97 & 28,61 & $-0,64$ \\
3 & Jumlah Biaya Usaha & 97,65 & 83,04 & 14,61 \\
& Koreksi Fiskal & WP & BENCH & SELISIH \\
1 & CTTOR / PPM & 0,07 & 0,3 & $-0,23$ \\
& Penghasilan \& Biaya diluar usaha & WP & BENCH & SELISIH \\
1 & Pl & 1,37 & 8,67 & $-7,3$ \\
2 & Bl & 0,06 & 0,06 & 0 \\
& Netto (pl-bl) & 1,31 & 8,61 & $-7,3$ \\
& Objek Pemotongan dan Pemungutan PPh & WP & BENCH & SELISIH \\
1 & Gaji & 14,98 & 14,69 & 0,29 \\
2 & Sewa & 0,51 & 2,94 & $-2,43$ \\
3 & Bunga & 69,68 & 0 & 69,68 \\
4 & Input lain & 10,7 & 22,53 & $-11,83$ \\
\hline
\end{tabular}

\section{Aspek Biaya Usaha}

a. Berdasarkan pembandingan diatas diketahui bahwa kinerja operasional perusahaan sedikit di bawah benchmark

b. Rasio-rasio Wajib Pajak terhadap benchmark menunjukkan bahwa proporsi beban penyusutan dan beban sewa terhadap penjualan masih dibawah benchmark. Rasio beban gaji terhadap penjualan sedikit diatas benchmark.

c. Rasio bunga dan input lain terhadap penjualan menunjukkan selisih yang cukup tinggi di atas benchmark. Untuk dapat melakukan analisis secara tepat terhadap hasil pembandingan tersebut, diperlukan pemahaman menyeluruh mengenai kondisi industri pada umumnya.

d. Dari selisih-selisih tersebut terlihat bahwa selisih Biaya bunga terhadap benchmark memiliki tingkat risiko ketidakwajaran yang paling tinggi. Untuk itu, penelitian perlu difokuskan pada akun-akun yang berkaitan dengan biaya bunga.

\section{Koreksi Fiskal}

a. CTTOR/PPM Wajib Pajak di bawah benchmark, yang berarti koreksi fiskal yang dilakukan wajib pajak masih di atas benchmark perusahaan sejenis.

\section{Penghasilan dan Biaya Luar Usaha}

a. Hasil pembandingan menunjukkan bahwa Penghasilan Luar Usaha Netto Wajib Pajak berada di bawah benchmark,

b. Rendahnya pl bisa terjadi karena adanya penghasilan luar usaha yang bersifat insidentil yang diterima oleh Wajib Pajak pada tahun yang bersangkutan, atau penghasilan lain yang diterima secara rutin oleh Wajib Pajak diluar dari usaha pokok Wajib Pajak yang tidak secara umum juga diterima oleh perusahaan lain dalam usaha sejenis.

c. Rasio Penghasilan Luar Usaha diatas secara netto berada di bawah benchmark, diperlukan pendalaman lebih lanjut mengenai penghasilan luar usaha ini 


\section{Objek Pemotongan dan Pemungutan PPh}

a. Hasil analisis menunjukkan bahwa Rasio sewa dan input lain terhadap Penjualan berada dibawah benchmark, perlu diteliti lebih dalam apakah masih terdapat potensi Pemotongan dan Pemungutan PPh Pasal 23 yang masih dapat digali dengan memperhatikan alasan-alasan yang mungkin mengenai rendahnya rasio tersebut.

b. Rasio Bunga/Penjualan terlihat berada di atas benchmark, menunjukkan tingginya potensi PPh Pemotongan dan Pemungutan yang masih dapat digali.

\section{Pengujian Benchmark Pembiayaan Konsumen}

Tabel 7. Rasio Benchmark Pembiayaan 2005

\begin{tabular}{llccc}
\hline No & \multicolumn{1}{c}{ Rasio Benchmarking } & $\mathbf{2 0 0 5}$ \\
\hline & Biaya Usaha & WP & BENCH & SELISIH \\
1 & HPP & 0 & 0 & 0 \\
2 & Biaya Usaha Lain & 55,41 & 74,66 & $-19,25$ \\
3 & Jumlah Biaya Usaha & 55,41 & 74,66 & $-19,25$ \\
& Koreksi Fiskal & WP & BENCH & SELISIH \\
1 & CTTOR / PPM & 0,26 & 0,42 & $-0,15$ \\
& Penghasilan \& Biaya diluar usaha & WP & BENCH & SELISIH \\
1 & Pl & 4,68 & 8,91 & $-4,23$ \\
2 & Bl & 2,22 & 5,49 & $-3,27$ \\
& Netto (pl-bl) & 2,46 & 3,42 & $-0,96$ \\
& Pemotongan dan Pemungutan PPh & WP & BENCH & SELISIH \\
1 & Gaji & 14,68 & 20,16 & $-5,48$ \\
2 & Sewa & 1,75 & 0,49 & 1,26 \\
3 & Bunga & 19,84 & 2,82 & 17,02 \\
4 & Input lain & 15,32 & 7,44 & 7,88 \\
\hline
\end{tabular}

Tabel 8. Rasio Benchmark Pembiayaan 2006

\begin{tabular}{llccc}
\hline No & \multicolumn{1}{c}{ Rasio Benchmarking } & \multicolumn{3}{c}{ 2006 } \\
\hline & Biaya Usaha & WP & BENCH & SELISIH \\
1 & HPP & 0 & 0 & 0 \\
2 & Biaya Usaha Lain & 80,04 & 52,74 & 27,3 \\
3 & Jumlah Biaya Usaha & 80,04 & 52,74 & 27,3 \\
& Koreksi Fiskal & WP & BENCH & SELISIH \\
1 & CTTOR / PPM & 0,27 & 0,39 & $-0,12$ \\
& Penghasilan \& Biaya diluar usaha & WP & BENCH & SELISIH \\
1 & Pl & 7,08 & 0,44 & 6,64 \\
2 & Bl & 0,95 & 16,47 & $-15,52$ \\
& Netto (pl-bl) & 6,13 & $-16,03$ & 22,16 \\
& Pemotongan dan Pemungutan PPh & WP & BENCH & SELISIH \\
1 & Gaji & 16,46 & 12,63 & 3,83 \\
2 & Sewa & 1,89 & 1,53 & 0,36 \\
3 & Bunga & 21,92 & 6,72 & 15,2 \\
4 & Input lain & 14,86 & 28,19 & $-13,33$ \\
\hline
\end{tabular}


Tabel 9. Rasio Benchmark Pembiayaan 2007

\begin{tabular}{llccc}
\hline No & \multicolumn{1}{c}{ Rasio Benchmarking } & \multicolumn{3}{c}{$\mathbf{2 0 0 7}$} \\
\hline & Biaya Usaha & WP & BENCH & SELISIH \\
1 & HPP & 0 & 0 & 0 \\
2 & Biaya Usaha Lain & 63,19 & 52,74 & 10,45 \\
3 & Jumlah Biaya Usaha & 63,19 & 52,74 & 10,45 \\
& Koreksi Fiskal & WP & BENCH & SELISIH \\
1 & CTTOR / PPM & 0,16 & 0,39 & $-0,23$ \\
& Penghasilan \& Biaya diluar usaha & WP & BENCH & SELISIH \\
1 & Pl & 8,31 & 0,44 & 7,87 \\
2 & Bl & 0,71 & 16,47 & $-15,76$ \\
& Netto (pl-bl) & 7,6 & $-16,03$ & 23,63 \\
& Pemotongan dan Pemungutan PPh & WP & BENCH & SELISIH \\
1 & Gaji & 18,53 & 12,63 & 5,9 \\
2 & Sewa & 2,18 & 1,53 & 0,65 \\
3 & Bunga & 21,06 & 6,72 & 14,34 \\
4 & Input lain & 12,52 & 28,19 & $-15,67$ \\
\hline
\end{tabular}

\section{Aspek Biaya Usaha}

a. Berdasarkan pembandingan diatas diketahui bahwa kinerja operasional perusahaan di bawah benchmark.

b. Tingginya beban usaha tersebut karena HPP yang berada diatas benchmark.

c. Rasio-rasio Wajib Pajak terhadap benchmark menunjukkan bahwa proporsi beban gaji, beban penyusutan dan beban sewa terhadap penjualan masih di atas benchmark..

d. Rasio bunga dan input lain terhadap penjualan menunjukkan selisih yang cukup tinggi di atas benchmark. Untuk dapat melakukan analisis secara tepat terhadap hasil pembandingan tersebut, diperlukan pemahaman menyeluruh mengenai kondisi industri pada umumnya.

e. Selisih Biaya bunga terhadap benchmark memiliki tingkat risiko ketidakwajaran yang paling tinggi. Untuk itu, penelitian perlu difokuskan pada akun-akun yang berkaitan dengan biaya bunga.

\section{Koreksi Fiskal}

a. CTTOR/PPM Wajib Pajak di bawah benchmark, yang berarti koreksi fiskal yang dilakukan wajib pajak sudah di atas benchmark perusahaan sejenis.

b. Rasio WP lebih rendah dibanding benchmark, harus dianalisis secara hati-hati apakah Wajib Pajak yang bersangkutan jmelakukan kompensasi kerugian, sebelum dapat menarik kesimpulan adanya indikasi bahwa Koreksi Fiskal Positif/Negatif yang dilakukan ternyata lebih rendah dari yang seharusnya.

\section{Penghasilan dan Biaya Luar Usaha}

a. Hasil pembandingan menunjukkan bahwa Penghasilan Luar Usaha Netto Wajib Pajak berada diatas benchmark, dengan nilai pl dan bl keduanya diatas benchmark. 
b. Tingginya pl bisa terjadi karena adanya penghasilan luar usaha yang bersifat insidentil yang diterima oleh Wajib Pajak pada tahun yang bersangkutan, atau penghasilan lain yang diterima secara rutin oleh Wajib Pajak diluar dari usaha pokok Wajib Pajak yang tidak secara umum juga diterima oleh perusahaan lain dalam usaha sejenis.

c. Rasio Penghasilan Luar Usaha diatas secara netto berada diatas benchmark, pendalaman lebih lanjut mengenai penghasilan luar usaha ini tidak perlu menjadi prioritas.

\section{Objek Pemotongan dan Pemungutan PPh}

a. Hasil analisis menunjukkan bahwa Rasio input lain terhadap Penjualan berada dibawah benchmark, perlu diteliti lebih dalam apakah masih terdapat potensi $\mathrm{PPh}$ Pemotongan dan Pemungutan yang masih dapat digali dengan memperhatikan alasan-alasan yang mungkin mengenai rendahnya rasio tersebut.

b. Rasio Bunga/Penjualan terlihat berada di atas benchmark, menunjukkan tingginya potensi PPh Pemotongan dan Pemungutan yang masih dapat diintensifkan.

\section{SIMPULAN}

Penelitian ini mengkaji bagaimana penerapan rasio benchmarking digunakan untuk mengetahui kewajaran laporan keuangan dan sampai sejauh mana pelaksanaan kewajiban perpajakan dari para wajib pajak khususnya lembaga keuangan seperti sektor Perbankan, Asuransi dan Pembiayaan Konsumen.

Pemilihan 4 aspek rasio tersebut didasarkan pada pertimbangan bahwa rasio yang digunakan sedapat mungkin mampu memberikan gambaran secara menyeluruh atas kegiatan operasional perusahaan dalam suatu periode dan berkaitan dengan semua jenis pajak yang menjadi kewajiban Wajib Pajak.

Wajib Pajak yang memiliki kinerja keuangan yang lebih rendah daripada benchmark, tidak selalu berarti bahwa wajib pajak tersebut tidak melakukan kewajiban pajaknya dengan benar..Namun perlu melakukan analisa lebih mendalam terhadap bisni Wajib Pajak.Dengan adanya Total benchmarking, diharapkan Direktorat Jenderal Pajak dapat secara sistematis menilai kewajaran kinerja keuangan dan pemenuhan kewajiban perpajakan Wajib Pajak serta mendeteksi wajib pajak dengan risiko ketidakpatuhan yang tinggi, untuk kemudian dapat dilakukan tindak lanjut yang sesuai. 


\section{DAFTAR PUSTAKA}

Anand G, Kodali R. 2008. Benchmarking the Benchmarking Models. Benchmarking: AnInternational Journal 15 (3) : 257-291.

Antaranews.com. Selasa, 8 Januari 2013. Pemerintah kejar target penerimaan pajak 2013

Dattakumar R, Jagadeesh R. 2003. A Review of Literature on Benchmarking. Benchmarking: An International Journal 10 (3) : 176-209.

Denkena B, Apitz R, Liedtke C. 2006. Knowledge-based Benchmarking of Production Performance Benchmarking: An International Journal 13 (1/2): 190-199.

Dragolea L, Cotirlea D. 2009. Benchmarking-A Valid Strategy for the Long Term ?. Annales Universitatis Apulensis Series Oeconomica 11 (2) : 813-826.

Elmuti D, Yunus K. 1997. An Overview of Benchmarking Process: A Tool for Continuous Improvement and Competitive Advantage. Benchmarking for Quality Management \& Technology 4 (4): 229-243.

Grundberg T. 2003. A Review of Improvement Methods in Manufacturing Operations. International Journal of Productivity and Performance Management 52 (2): 89-93.

Ma'arif MS., Hendri T. 2003. Manajemen Operasi. Jakarta: PT. Grasindo. Martin F. 2008. A Performance Technologist's Approach to Process Performance Improvement. International Society for Performance Improvement. 47 (2): 30-40.

Moriarty JP, Smallman C. 2009. En Route a Theory of Benchmarking. Benchmarking : An International Journal 16 (4): 484-503.

Nyoman Darmayasa dan Nyoman Sentosa Hardika.2011.Perencanaan Pajak dari Aspek Rasio Total Benchmarking, Kebijakan Akuntansi, dan Administrasi Sebagai Strategi Penghematan Pajak.Jurnal Bisnis dan Kewirausahaan, Vol 7 No. 3 Nopember 2011.

PER 70/PJ/2007.Tentang Tata Cara Pelaksanaan Konseling Terhadap Wajib Pajak Sebagai Tindak Lanjut Surat Himbauan.

Pierre JS, Delisle S. 2006. An Expert Diagnosis System for the Benchmarking of SME's Performance. Benchmarking : An International Journal 13 $(1 / 2): 106-119$.

SE-96/PJ/2009 Tentang Rasio Total Benchmarking dan Petunjuk Pemanfaatannya.

SE-11/PJ/2010 Tentang Penetapan Rasio Total Benchmarking Tahap II.

SE-68/PJ/2010 Tentang Penetapan Rasio Total Benchmarking Tahap III.

SE-105/PJ/2010 Tentang Penetapan Rasio Total Benchmarking Tahap IV.

SE-139/PJ/2010 Tentang Penetapan Rasio Total Benchmarking Tahap V.

Steven et al. 2003. Key Management Models: The Management Tools and Practices that will Improve Your Business. London: Prentice Hall.

Theresia Woro Damayanti, dan Eko Sukmono A. Ratio Total Benchmarking Sesuaikah Dengan Kondisi Wajib Pajak? (Studi Pada Empat Perusahaah Rokok Yang Terdaftar Di BEI). 2011. Seminar Nasional Ilmu Ekonomi Terapan Fakultas Ekonomi UNIMUS.

Undang-undang Nomor 28 Tahun 2007 tentang Ketentuan Umum dan Tata CaraPerpajakan 
Undang-undang Nomor 36 Tahun 2008 tentang Pajak Penghasilan

Undang-undang Nomor 42 Tahun 2009 tentang Pajak Pertambahan Nilai Barang dan Jasa dan Pajak Penjualan Atas Barang Mewah

Waluyo dan Wirawan B. Ilyas, 2002.Perpajakan Indonesia.Jakarta: Salemba Empat.

Watson GH. 1996. Strategic Benchmarking: How to Rate Your Company's Performance against the World's Best. Terjemahan. Jakarta: PT. Gramedia Pustaka Utama.

Williams SE. 2008. What has Benchmarking go to do with Evaluation ?. Di dalam : Mini Workshop AES International Conference. Perth.

Yasin MM. 2002. The Theory and Practice of Benchmarking: Then and Now. Benchmarking : An International Journal 9 (3) : 217-243. 